\title{
In vitro ANTIGIARDIAL ACTIVITY OF THE CYSTEINE PROTEASE INHIBITOR E-64
}

\author{
Thaís Batista de CARVALHO, Teresa Cristina Goulart OLIVEIRA-SEQUEIRA \& Semíramis GUIMARÃES
}

\begin{abstract}
SUMMARY
The quest for new antiparasitic alternatives has led researchers to base their studies on insights into biology, host-parasite interactions and pathogenesis. In this context, proteases and their inhibitors are focused, respectively, as druggable targets and new therapy alternatives. Herein, we proposed to evaluate the in vitro effect of the cysteine protease inhibitor E-64 on Giardia trophozoites growth, adherence and viability. Trophozoites $\left(10^{5}\right)$ were exposed to E-64 at different final concentrations, for 24,48 and $72 \mathrm{~h}$ at 37 ${ }^{\circ} \mathrm{C}$. In the growth and adherence assays, the number of trophozoites was estimated microscopically in a haemocytometer, whereas cell viability was evaluated by a dye-reduction assay using MTT. The E-64 inhibitor showed effect on growth, adherence and viability of trophozoites, however, its better performance was detected in the $100 \mu \mathrm{M}$-treated cultures. Although metronidazole was more effective, the E-64 was shown to be able to inhibit growth, adherence and viability rates by $\geq 50 \%$. These results reveal that E- 64 can interfere in some crucial processes to the parasite survival and they open perspectives for future investigations in order to confirm the real antigiardial potential of the protease inhibitors.
\end{abstract}

KEYWORDS: Giardia duodenalis; Protease inhibitor; Trophozoites; Growth; Adherence; Viability.

\section{INTRODUCTION}

Giardia duodenalis (syn. Giardia lamblia, Giardia intestinalis), a worldwide zoonotic intestinal protozoan, is one of the major causes of non-viral diarrheal disease in humans. Despite giardiasis has a global distribution, higher infection rates (20-60\%) have been reported for developing countries, mainly among socially and economically deprived populations ${ }^{22}$. Since in developed areas, infections rates are lower and G. duodenalis is often involved in numerous outbreaks that have been attributed to an inappropriate water treatment ${ }^{1}$. Considering the infection impact on health and on socio-economic improvements of developing nation's population, Giardia was recently included in the WHO Neglected Diseases Initiative, a group including pathogens that have a common link with poverty ${ }^{20}$. In these areas, giardiasis is a common cause of diarrhea in nursery and school children ${ }^{22}$, especially in undernourished individuals, which in turn, gives rise to nutritional deficiencies leading to growth failure and cognitive impairment ${ }^{20}$.

So far, drug intervention has been recommended as a preventive strategy to limit and reduce the transmission of giardiasis. Currently, some therapeutic measures have been available in clinical practice for the treatment of giardiasis, highlighting acridine, 5-nitroimidazole, 5-nitrofurans, 5-nitrothiazoles and benzimidazole derivates ${ }^{27}$. For decades, the most prescribed antigiardial drug is the metronidazole, a 5-nitroimidazole compound that has a recognized antigiardial activity with cure rates ranging from 80 to $95 \%{ }^{21}$. Despite its efficiency, treatment shows undesirable side effects, failures are common and evidences suggest the emergence of drug resistance ${ }^{2,9,14}$. Therefore, there is an increasing interest for new antigiardial agents that can be effective against the parasite, less harmful for the host and may provide options for refractory cases, especially for children, who may require treatment often because of reinfections.

Nowadays, the quest for new antiparasitic alternatives has led researchers to base their studies on insights into biology, hostparasite interactions and pathogenesis. In light of this, advances in the understanding of the biochemistry and molecular biology of parasites have led to a better understanding of molecules which play a role in biological, metabolic and physiological processes. Among these molecules, the proteolytic enzymes or proteases have excited the researcher's interest, once they have been identified as important virulent factors as well as potential chemotherapeutic targets in parasites. Considering that proteolytic activity is naturally regulated by specific inhibitors, the selective inhibition of crucial proteases can be a promising strategy to develop new antiparasitic therapies ${ }^{19}$. In this context, it is important to emphasize that proteases have been validated as druggable targets as evidenced by the use of protease inhibitors as effective therapy for hypertension, diabetes, osteoporosis, certain cancers and AIDS ${ }^{17,28}$. In relation to parasites, several protease targets have been validated by genetic or chemical knockout in protozoan parasites, and many other 
enzymes appear promising as targets but they require more investigations for validation, or to identify viable drug leads. So, interesting results have been reported in studies with parasitic infections such as malaria, leishmaniasis and Chagas disease and they have provided important evidences that these substances selectively inhibit parasite proteases without affecting host homologues ${ }^{17}$.

With respect to Giardia, notwithstanding recent studies have shed light on trophozoites proteases and their involvement in metabolism and physiologic processes ${ }^{4,5,12,23}$ relatively little is known about the effect of protease inhibitors on vital processes of this parasite. To date, as far as we know, there are few studies that have evaluated the in vitro and in vivo performance of protease inhibitors on multiplication ${ }^{8,11}$ and on encystation/excystation ${ }^{7,23,24}$ of the parasite. Thus, considering the aspects above, here we report the in vitro effects of E-64, a specific cysteine protease inhibitor, on axenic trophozoites growth and adherence abilities, and viability. The results assembled here may open perspectives to pursue the development of further investigations in order to assess protease inhibitors as potential antigiardial agents.

\section{MATERIALS AND METHODS}

Parasite and cultivation conditions: $G$. duodenalis axenic trophozoites, BTU-11 strain, were axenically cultivated in filter-sterilized TYI-S-33 (Tryptcase, yeast extract, iron serum) medium, modified by KEISTER ${ }^{13}$ in $5 \mathrm{~mL}$ Vacutainer ${ }^{\circledR}$ tubes at $37^{\circ} \mathrm{C}$. The strain isolated in Brazil at the Giardiasis Laboratory (IB/UNESP) in Botucatu, São Paulo was established from cysts of a symptomatic patient presenting diarrhea, flatulence, abdominal cramps and resistance to conventional therapy. Trophozoites harvested in log-phase growth $72 \mathrm{~h}$ postinoculation, after chilling in bath ice for $10 \mathrm{~min}$, were collected by centrifugation at $250 \times \mathrm{g}$ for $15 \mathrm{~min}$ at $4{ }^{\circ} \mathrm{C}$. Pooled cells were resuspended in sterile phosphatebuffered saline (PBS; $\mathrm{pH}$ 7.2) and the total number of trophozoites was counted microscopically in a haemocytometer (Neubauer cell-counter chamber) and adjusted to an inoculum of $10^{5}$ parasites.

Preparation of inhibitor: E-64 [(L-trans-epoxysuccinyl-Lleucylamido-(4-guanidino)-butane], a commercially available cysteine protease inhibitor was purchased from Sigma. The inhibitor was prepared at one $\mathrm{mM}$ in aqueous solution and stored at $-20^{\circ} \mathrm{C}$, until required. The inhibitor stock solution was diluted in sterile phosphate buffered saline (pH 7.2) at final concentrations of 10,50 and $100 \mu \mathrm{M}$ and sterilized in $0.22 \mu \mathrm{m}$ filter. The assayed concentrations were established according to inhibitor effective concentration ${ }^{3}$.

Growth inhibition assay: Firstly, an inoculum of $10^{5}$ trophozoites were incubated in TYI-S-33 medium ( $4.5 \mathrm{~mL} /$ tube) containing the inhibitor at different concentrations $(10,50$ and $100 \mu \mathrm{M})$ for 24,48 and $72 \mathrm{~h}$ at $37^{\circ} \mathrm{C}$. After incubation, the tubes were cooled for $10 \mathrm{~min}$, centrifuged at $250 \times \mathrm{xg}\left(10 \mathrm{~min}, 4^{\circ} \mathrm{C}\right)$ and the population density of cultures were estimated by counting in a haemocytometer. As controls, cultures containing only the parasites and cultures treated with metronidazole at $40 \mu \mathrm{g} / \mathrm{mL}^{15}$ were included in all the assays and submitted to the same experimental conditions. For each E-64 concentration assessed, three tubes were screened and the protease inhibitor activity on the parasite growth was evaluated comparing the number of organisms in inhibitortreated cultures with their number in controls. The results were expressed as the trophozoites number and growth inhibition percentage.
Adherence assay: The E-64 effect on adherence of Giardia trophozoites was analyzed as previously described by EDLIND et al. ${ }^{10}$, with slight modifications. An inoculum of $10^{5}$ organisms was incubated in TYI-S-33 medium for four hours at $37^{\circ} \mathrm{C}$. The medium with unattached cells was replaced with one supplemented with E-64 at 10,50 and $100 \mu \mathrm{M}$. After incubation for 24 and $48 \mathrm{~h}$ at $37^{\circ} \mathrm{C}$, adherent cells were dislodged by a $10 \mathrm{~min}$ on ice, centrifuged at $250 \mathrm{xg}$ and the number of attached cells was determined using a haemocytometer. Control assays were performed under similar experimental conditions with cultures in the absence of E-64 and cultures treated with metronidazole at $40 \mu \mathrm{g} / \mathrm{mL}^{15}$. For each inhibitor concentration, three tubes were assayed and the effect on adhesion capacity was evaluated comparing the number of organisms in E-64-treated cultures with their number in control cultures. The results were expressed as number of attached cells (percentage of control).

Cell viability assay: The effect of E-64 on trophozoites viability was evaluated by the quantitative colorimetric MTT-tetrazolium salt [3-(4,5-dimethilthiazol-2-yl)-2,5-diphenyl tetrazolium bromide] technique, as previously described by PONCE-MACOTELA et al. ${ }^{18}$. Briefly, trophozoites $\left(10^{5}\right)$ exposed to each E-64 concentration for 48 and $72 \mathrm{~h}$ were transferred to 1.5 Eppendorf $^{\circledR}$ tubes, washed with PBS (pH7.4) and incubated for $60 \mathrm{~min}$ at $37^{\circ} \mathrm{C}$ in a solution containing 40 $\mu \mathrm{L}$ of MTT ( $5 \mathrm{mg} / \mathrm{mL}$; Sigma) and $20 \mu \mathrm{L}$ of the catalyst phenazinemethosulfate (PMS $2.5 \mathrm{mg} / \mathrm{mL}$; Sigma). Then, the cells were pelleted by centrifugation and the purple product obtained by the conversion of MTT to the formazan was resuspended in isopropanol/hydrochloric acid. The assay was performed in triplicate and aliquots of $150 \mu \mathrm{L}$ were collected and the optical densities of each sample were measured at 540 $\mathrm{nm}$. The parasite viability was calculated regarding the untreated cultures (100\% viability).

Statistical analysis: To evaluate E-64 effect on the growth, adherence and viability of Giardia trophozoites, a factorial design layout was employed for counting data following multiple comparisons. Data were submitted to analyze the variance (ANOVA) and the means were compared by Tukey's test. All analyses were conducted in SAS 9.2 for Windows (SAS Institute Inc., Cary, NC) and $p$-values less than 0.05 were deemed statistically significant. The inhibitory concentrations at 50\% (IC50) were calculated from dose-response curves by linear regression analysis.

\section{RESULTS AND DISCUSSION}

As many efforts have been made to search new alternatives for Giardia infection treatment, the assessment of a drug potential requires suitable models that allow identifying the biological processes on which they can interfere. For this purpose, assays for in vitro screening are a preliminary step and advances in trophozoites axenic cultivation have allowed the investigation of antigiardial activity of a range of compounds, especially, in relation to their ability to exert effect on trophozoites growth, adherence and viability. The present study led to some interesting findings concerning the in vitro activity of the cysteine protease inhibitor E-64 on axenic trophozoites.

As shown in Figure 1, E-64 exerted inhibitory activity on parasite multiplication in a dose dependent manner. Considering the assayed concentrations of 10,50 and $100 \mu \mathrm{M}$, growth inhibition was observed in 
cultures exposed to the highest of them, in which the number of parasites recovered was significantly lower than that obtained in untreated cultures $(p<0.05)$. The inhibitory concentrations at 50\% (IC50) were 144.29 $\mu \mathrm{M}$ for $24 \mathrm{~h}, 53.72 \mu \mathrm{M}$ for $48 \mathrm{~h}$ and $27.02 \mu \mathrm{M}$ for $72 \mathrm{~h}$. At both 48 and $72 \mathrm{~h}$, growth reduction by $\geq 50 \%$ and $\geq 70 \%$ were observed in cultures treated with 50 and $100 \mu \mathrm{M}$, respectively $(p<0.05)$. A significant level of inhibition $(\sim 80 \%)$ was detected in $72 \mathrm{~h}$ cultures treated with the $100 \mu \mathrm{M}$, but the reduction rate was still lower than that obtained in metronidazole-treated cultures. In adherence assays (Fig. 2), only the concentrations of 50 and $100 \mu \mathrm{M}$ were able to promote detachment of trophozoites. The IC50 values after 24 and $48 \mathrm{~h}$ were $128.65 \mu \mathrm{M}$ and $33.80 \mu \mathrm{M}$ respectively. The greater activity was induced by the inhibitor at $100 \mu \mathrm{M}$ after $48 \mathrm{~h}(p<0.05)$ when only $10 \%$ of trophozoites remained attached. Despite E-64 markedly diminished parasite adherence at 100 $\mu \mathrm{M}$, the rates of metronidazole inhibition were higher. In both growth and adherence assays, E-64 exhibited a dose-response effect, however by light microscope observations, this activity was not accompanied by marked changes in trophozoites morphology as body swollen and reduction of flagellar beating frequency.

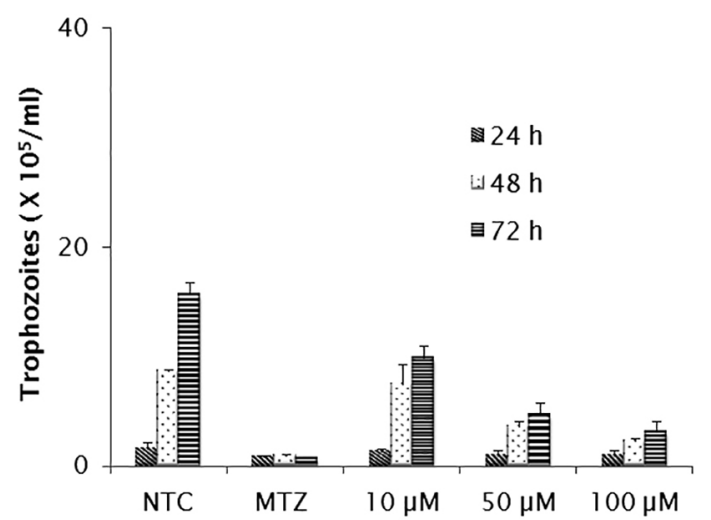

Fig. 1 - In vitro effect of E-64 inhibitor $(\mu \mathrm{M})$ on the growth of $G$. duodenalis trophozoites, after incubation for 24, 48 and 72 hours. Non-treated cultures (NTC) and metronidazoletreated cultures (MTZ) were included in all assays. Data expressed as means of trophozoites number $\left(10^{5}\right) \pm$ standard deviation (SD) in assays performed in triplicate.

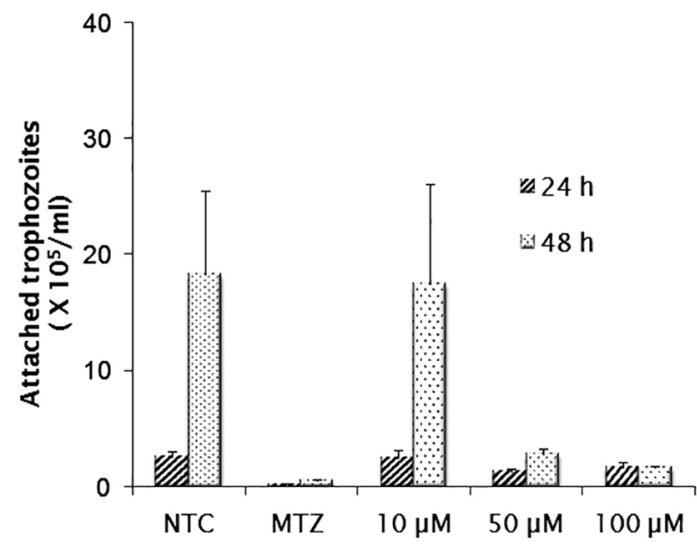

Fig. 2 - In vitro effect of E-64 inhibitor $(\mu \mathrm{M})$ on the adherence of $G$. duodenalis trophozoites, after incubation for 24 and 48 hours. Non-treated cultures (NTC) and metronidazole-treated cultures (MTZ) were included in all assays. Data expressed as means of attached trophozoites number $\left(10^{5}\right) \pm$ standard deviation (SD) in assays performed in triplicate.
As in the growth and adherence assays, E-64 at $100 \mu \mathrm{M}$ showed a very significant reduction of viability rate in comparison to non-treated cultures after $48 \mathrm{~h}$ (Fig. 3) $(p<0.05)$. The highest rates were detected after $48 \mathrm{~h}$, when the inhibitor at 50 and $100 \mu \mathrm{M}$ was able to kill $80 \%$ and $93 \%$ of the trophozoites, respectively $(p<0.05)$. However, this effect was lower than that obtained by exposure to metronidazole $(p<0.05)$.

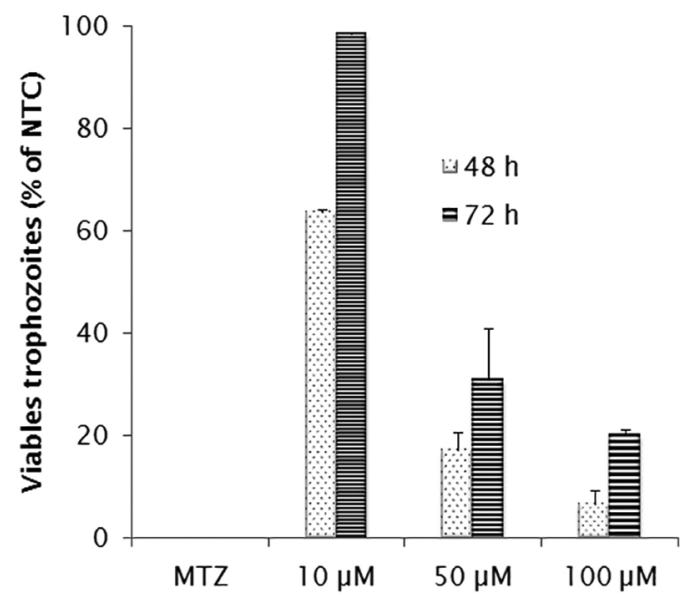

Fig. 3 - Viability (MTT assay) of $G$. duodenalis after incubation with different concentrations of E-64 inhibitor $(\mu \mathrm{M})$. Cultures treated with metronidazole (MTZ) at $40 \mu \mathrm{g} / \mathrm{mL}$ were included as control. The values correspond to mean \pm standard deviation (SD) in assays performed in triplicate.

So far, the most widely used drug against Giardia infection is the metronidazole, a 5'-nitroimidazole derivate, although there are some problems related to resistance and toxicity. Once many antiparasitic drugs currently in use show the same disadvantages, recently, investigations have identified promising antiparasitic drug candidates as well as potential targets in parasites. In this context, proteases and their inhibitors are focused, respectively, as druggable targets and new therapy alternatives.

In the last years, several investigations have focused the potential of protease inhibitors in important parasitic infections such as malaria, Chagas' disease, leishmaniasis and toxoplasmosis ${ }^{17}$ and they have revealed promising insights on the use of these substances, especially those against thiol or cysteine proteases. Regarding to Giardia, advances in the study of its proteases had become clear that this protozoan is actively proteolytic and contain multiple proteases, with the predominance of the cysteine peptidases that are responsible for the main proteolytic activity ${ }^{4,5,12,26}$.

In the present study, although metronidazole was very effective, the cysteine protease inhibitor E-64 was shown to be also efficient in affecting the parasite growth, adherence and viability. These biological parameters were inhibited by $\geq 50 \%$ at concentrations of 50 and $100 \mu \mathrm{M}$. With respect to Giardia, to date, there are only two studies that evaluate the performance of inhibitors on the life forms of the parasite. In one of these investigations ${ }^{8}$, antiretroviral protease inhibitors (Kaletra ${ }^{\circledR}$, ritonavir and saquinavir) were assessed in vitro for their activity on trophozoite proliferation and the results revealed that Kaletra ${ }^{\circledR}$ was the most effective of them. More recently, in vitro and in vivo assays to evaluate the antigiardial potential of E-64 showed a significant inhibitory effect on parasite growth and on the efficiency of encystation ${ }^{11}$. 
Interestingly, E-64 was also able to inhibit trophozoite adherence and a marked detachment of $90 \%$ was observed in cultures exposed to the substance at $100 \mu \mathrm{M}$. It is important to emphasize that the attachment of Giardia trophozoites to intestinal mucosa is an essential factor for their colonization and survival in the host as well as for giardiasis pathogenesis. According to some authors, the adherence process has been considered as a potential target for chemotherapeutic alternatives that induce detachment and/or prevent the adhesion of parasite on the intestinal epithelium ${ }^{16}$. Another point to make is that substances that are capable of altering microtubule assembly of the trophozoites have the potential to affect a range of biological processes such as cytokinesis, locomotion, adhesion and detachment, situations that can enhance reduction in cell viability ${ }^{16}$.

Despite the E-64 in vitro effect, light microscope observations do not reveal marked alterations in trophozoites morphology. Although E-64 is a very useful cysteine inhibitor, it is known that its hydrophilic character is a property that can interfere in its cell permeability and impair the effective penetration through cell membranes ${ }^{25}$. In contrast to E-64, its synthetic analogues E-64c and E-64d act as potent membranepermeable cysteine protease inhibitors that can permeate an intact cell. Recently, in a study on the structure and function of the Giardia endomembrane system and the cysteine proteases, DUBOIS ${ }^{6}$ reported that growth was not affected by E-64d up to $50 \mu \mathrm{M}$. In addition, according to this author, the survival of trophozoites in the presence of this inhibitor did not differ from that observed in the untreated cultures. In view of these findings with E-64d and considering the observations in the present study when E-64 was able to reduce parasite growth by $\geq 50 \%$ at concentrations of 50 and $100 \mu \mathrm{M}$, future studies are a prerequisite to elucidate in more detail the effects of E-64 and its derivatives on Giardia biological processes.

The findings assembled herein lead us to suggest that E-64 can interfere in some crucial process in relation to the parasite survival, but until today little is known about the efficacy and safety of this protease inhibitor in vivo. So, it is suitable that the concentrations assessed in vitro must be tested in vivo before a definitive statement can be made on its antiparasitic potential. Even so, our results provide insights on protease inhibitors targeting parasite cysteine proteases open perspectives for future investigations in order to confirm the real antigiardial potential of E-64 and other potent inhibitors of cysteine proteases.

\section{RESUMO}

\section{Atividade in vitro do inibidor de cisteína-proteases E-64 sobre trofozoítos de Giardia}

As cisteína-proteases estão entre os alvos mais promissores para o desenvolvimento de novos agentes terapêuticos, visto que participam de eventos fundamentais do ciclo de vida de muitos microorganismos, inclusive Giardia. Como a atividade das proteases pode ser controlada por inibidores específicos, essas substâncias têm sido avaliadas quanto ao potencial antiparasitário. Diante disso, o presente estudo teve por objetivo avaliar o efeito in vitro do inibidor de cisteína-proteases E-64 sobre o crescimento, a aderência e a viabilidade de trofozoítos de cepa de Giardia isolada em Botucatu. Nos ensaios de crescimento e aderência, o número de trofozoítos foi estimado microscopicamente em hemocitômetro, enquanto que a viabilidade celular foi avaliada pelo método do MTT. No presente estudo, embora o metronidazol tenha se apresentado bastante efetivo, o E-64 mostrou ser capaz de inibir o crescimento, a aderência e a viabilidade em taxas superiores a 50\%, especialmente nos cultivos expostos à concentração de $100 \mu \mathrm{M}$. A despeito de preliminares, esses resultados demonstram que o inibidor E-64 pode interferir em processos primordiais para a sobrevivência do parasita, além do que, abrem novas perspectivas para investigações futuras a fim de se avaliar o real potencial giardicida dos inibidores de proteases.

\section{ACKNOWLEDGEMENTS}

The authors are grateful to the student's fellowship granted by the Brazilian agency CAPES.

\section{REFERENCES}

1. Adam RD. Biology of Giardia lamblia. Clin Microbiol Rev. 2001;14:447-75.

2. Barat LM, Bloland PB. Drug resistance among malaria and other parasites. Infect Dis Clin North Am. 1997;11:969-87.

3. Beynon RJ, Bond JS, editors. Proteolytic enzymes: a practical approach. Oxford: Oxford University Press: 1989.

4. Carvalho TB, David EB, Coradi ST, Guimarães S. Protease activity in extracellular products secreted in vitro by trophozoites of Giardia duodenalis. Parasitol Res. 2008;104:185-90.

5. Coradi ST, Guimarães S. Giardia duodenalis: protein substrates degradation by trophozoite proteases. Parasitol Res. 2006;99:131-6.

6. Dubois KN. Trafficking and biological function of Giardia cysteine proteases. [dissertation]. San Francisco: University of California; 2007.

7. Dubois KN, Abodeely M, Sakanari J, Craik CS, Lee M, McKerrow JH, et al. Identification of the major cysteine protease of Giardia and its role in encystation. J Biol Chem. 2008;283:18024-31.

8. Dunn LA, Andrews KT, McCarthy JS, Wright JM, Skinner-Adams TS, Upcroft P, et al. The activity of protease inhibitors against Giardia duodenalis and metronidazoleresistant Trichomonas vaginalis. Int J Antimicrob Agents. 2007;29:98-102.

9. Dunn LA, Burgess AG, Krauer KG, Eckmann L, Vanelle P, Crozet MD, et al. A newgeneration 5-nitroimidazole can induce highly metronidazole-resistant Giardia lamblia in vitro. Int J Antimicrob Agents. 2010;36:37-42.

10. Edlind TD, Hang TI, Chakraborty PR. Activity of the anthelmintic benzimidazoles against Giardia lamblia in vitro. J Infect Dis. 1990;162:1408-11.

11. Hussein EM, Dawoud HA, Salem AM, Atwa MM. Antiparasitic activity of cystine protease inhibitor E-64 against Giardia lamblia excystation in vitro and in vivo. J Egypt Soc Parasitol. 2009;39:111-9.

12. Jiménez JC, Uzcanga G, Zambrano A, Di Prisco MC, Lynch NR. Identification and partial characterization of excretory/secretory products with proteolytic activity in Giardia intestinalis. J Parasitol. 2000;86:859-62.

13. Keister DB. Axenic culture of Giardia lamblia in TYI-S-33 medium supplemented with bile. Trans R Soc Trop Med Hyg. 1983;77:487-8.

14. Lemée V, Zaharia I, Nevez G, Rabodonirina M, Brausser P, Ballet JJ, et al. Metronidazole and albendazole susceptibility of eleven clinical isolates of Giardia duodenalis from France. J Antimicrob Chemother. 2000;46:819-21.

15. McAllister TA, Annett CB, Cockwill CL, Olson ME, Wang Y, Cheeke PR. Studies on the use of Yucca schidigera to control giardiosis. Vet Parasitol. 2001;97:85-99. 
16. Machado M, Dinis AM, Salgueiro L, Custódio JBA, Cavaleiro C, Sousa MC. Anti-Giardia activity of Syzygium aromaticum essencial oil and eugenol: effects on growth, viability, adherence and ultrastructure. Exp Parasitol. 2011;127:732-9.

17. McKerrow JH, Rosenthal PJ, Swenerton R, Doyly P. Development of protease inhibitors for protozoan infections. Curr Opin Infect Dis. 2008;21:668-72.

18. Ponce-Macotela M, Rufino-González Y, de la Mora-de la Mora JI, González-Maciel A, Reynoso-Robles R, Martínez-Gordillo MN. Mortality and morphological changes in Giardia duodenalis induced by exposure to ethanolic extracts of Justicia spicigera. Proc West Pharmacol Soc. 2001;44:151-2.

19. Sajid M, McKerrow JH. Cysteine proteases of parasitic organisms. Mol Biochem Parasitol. 2002;120:1-21.

20. Savioli L, Smith H, Thompson A. Giardia and Cryptosporidium join the 'Neglected Diseases Initiative'. Trends Parasitol. 2006;22:203-8.

21. Thompson RC, Reynoldson JA, Mendis AH. Giardia and giardiasis. Adv Parasitol. $1993 ; 32: 71-160$

22. Thompson RC. Giardiasis as a re-emerging infectious disease and its zoonotic potential. Int J Parasitol. 2000;30:1259-67.
23. Touz MC, Nores MJ, Slavin I, Carmona C, Conrad JT, Mowatt MR, et al. The activity of a developmentally regulated cysteine proteinase is required for cyst wall formation in the primitive eukaryote Giardia lamblia. J Biol Chem. 2002;277:8474-81.

24. Ward W, Alvarado L, Rawlings ND, Engel JC, Franklin C, McKerrow JH. A primitive enzyme for a primitive cell: the protease required for excystation of Giardia. Cell. $1997 ; 89: 437-44$

25. Wilcox D, Mason RW. Inhibition of cysteine proteinases in lysosomes and whole cells. Biochem J. 1992;285:495-502.

26. Williams AG, Coombs GH. Multiple protease activities in Giardia intestinalis trophozoites. Int J Parasitol. 1995;25:771-8.

27. Yarden NT, Millman M, Lauwaet T, Davids BJ, Gillin FD, Dunn L, et al. Impaired parasite attachment as fitness cost of metronidazole resistance in Giardia lamblia. Antimicrob Agents Chemother. 2011;55:4643-51.

28. Zucca M, Savoia D. Current developments in the therapy of protozoan infections. Open Med Chem J. 2011;5:4-10.

Received: 6 December 2012

Accepted: 16 May 2013 